Samaha K, Dahawy K, Hussainey K \& Stapleton P (2012) The extent of corporate governance disclosure and its determinants in a developing market: The case of Egypt, Advances in Accounting, 28 (1), pp. 168-178.

This is the peer reviewed version of this article

NOTICE: this is the author's version of a work that was accepted for publication in Advances in Accounting. Changes resulting from the publishing process, such as peer review, editing, corrections, structural formatting, and other quality control mechanisms may not be reflected in this document. Changes may have been made to this work since it was submitted for publication. A definitive version was subsequently published in Advances in Accounting, [VOL 28, ISS 1 (2012)] DOI: http://dx.doi.org/10.1016/j.adiac.2011.12.001 


\section{THE EXTENT OF CORPORATE GOVERNANCE DISCLOSURE AND ITS DETERMINANTS IN A DEVELOPING MARKET: THE CASE OF EGYPT}

\author{
Khaled Samaha*, \\ American University in Cairo (AUC) \\ Department of Accounting, \\ School of Business, \\ The American University in Cairo (AUC), \\ Room 2058 - BEC Building, \\ P.O. Box 74, \\ New Cairo 11825, Egypt \\ Tel: +2 (02). 26153261 \\ E-mail: ksamaha@ aucegypt.edu
}

\section{Pamela Stapleton}

Manchester University

University of Manchester

Manchester Business School

Crawford House

Manchester M15 6PB

Tel: +44 (0) 1613063454

Fax: + 44(0) 1612754023

Email: Pam.stapleton@mbs.ac.uk

\author{
Khaled Dahawy \\ American University in Cairo (AUC) \\ Department of Accounting, \\ School of Business, \\ The American University in Cairo (AUC), \\ Room 2001 - BEC Building, \\ P.O. Box 74, \\ New Cairo 11825, Egypt \\ Tel: +2 (02) 26152342 \\ E-mail: dahawy@aucegypt.edu
}

\author{
Khaled Hussainey \\ Stirling University \\ Accounting and Finance Division \\ Stirling Management School \\ University of Stirling \\ Stirling FK9 4 LA \\ Tel: + 44 (0) 1786467286 \\ Fax: + 44 (0) 1786467308 \\ Email: Khaled.Hussainey@stir.ac.uk
}

\section{This paper is accepted for the publication at Advances in Accounting}

* Correspondence or enquiries should be addressed to Dr. Khaled Samaha, Room 2058 - BEC

Building, Accounting Department, The American University of Cairo, Fifth settlement, New

Cairo, Cairo, Egypt. Email: ksamaha@aucegypt.edu 


\section{ABSTRACT}

The aim of this paper is to assess the extent of corporate governance voluntary disclosure and the impact of a comprehensive set of corporate governance attributes (board composition, board size, CEO duality, director ownership, block-holder ownership and the existence of audit committee) on the extent of corporate governance voluntary disclosure in Egypt. The measurement of disclosure is based on published data created from a checklist developed by the United Nations, which was gathered from a manual review of financial statements and websites of a sample of Egyptian companies listed on Egyptian Stock Exchange (EGX). Although the levels of CG disclosure are found to be minimal, however disclosure is high for items that are mandatory under the Egyptian Accounting Standards (EASs). The failure of companies to disclose such information clearly shows some ineffectiveness and inadequacy in the regulatory framework in Egypt. Moreover, the phenomenon of non-compliance may also be attributed to the socio-economic factors in Egypt. Therefore, it is expected that Egyptian firms will take a long time to appraise the payback of increased CG disclosure. The findings indicate that that - ceteris paribus - the extent of CG disclosure: (1) is lower for companies with duality in position and higher ownership concentration as measured by block-holder ownership; and (2) increases with the proportion of independent directors on the board 
and firm size. The results of the study support theoretical arguments that companies disclose corporate governance information in order to reduce information asymmetry and agency costs and to improve investor confidence in the reported accounting information. The empirical evidence stems from this study enhances the understanding of the corporate governance disclosure environment in Egypt, as one of the emerging markets in the Middle East.

Keywords: Corporate governance, disclosure index, content analysis, developing markets, Egypt. 


\section{Introduction}

This paper focuses on one part of the reform process in Egypt - the development of the regulatory framework commencing in the late 1990s to improve corporate governance practices. Specifically, it is argued, if such practices follow international norms they can mitigate the financial problems of developing nations that include: weak and illiquid stock markets, economic uncertainties, weak investor protection, and frequent government intervention, (Tsamenyi et al., 2007; Gugler et al., 2003; Rabelo and Vasconcelos, 2002; Reed, 2002; Ahunwan, 2002); poor performance, and high levels of ownership concentration (Tsamenyi et al., 2007; Rabelo and Vasconcelos, 2002; Ahunwan, 2002); and state ownership of companies, weak legal and judiciary systems, weak institutions, and limited human resources capabilities (Mensah, 2002, Young et al., 2008).

However, de jure reform does not necessarily translate into reform of actual practice, and although many researchers have examined corporate governance in developed nations, much less academic study has been made of developing and emerging nations. This is an important omission for a number of reasons. Firstly, globalization, international trade, and international investment practices are creating significant pressures towards the development of corporate governance in these nations (Reed, 2002). 
Secondly, developing and emerging countries have tended to mimic the practices of developed nations, despite evidence, for example from Rabelo and Vasconncelos (2002), of the presence of differences between the factors giving rise to the need for corporate governance in developing nations and those in developed nations.

Thirdly, there are structural variations, such as the dominance of government ownership and/or family /close held companies that render the implementation of Western style corporate governance both of questionable value and troublesome (Mensah, 2002).

Fourthly, developing and emerging nations are not homogeneous. Specifically, there are major differences between the emerging countries of Eastern European and China, as there are between countries in the Middle East, North Africa and sub-Saharan Africa (Euromoney, 2007; Fawzy, 2004). Finally, while there may be increasing convergence among national and international corporate governance codes, there is also significant deviation in terms of disclosure practices and content of disclosure between countries (Bhuiyan and Biswas, 2007).

The paper investigates the determinants of corporate governance voluntary disclosures in Egypt. It contributes to disclosure and governance literature by studying corporate governance disclosure practice in a developing country, which is distinguished from most developed nations by four important characteristics (Fawzy, 2004). Firstly, most companies are closely held, secondly there is 
considerable state ownership of privatized companies, thirdly that board independence is weak and finally disclosure is not a common practice. While Bremer and Ellias (2007) note that Egyptian businesses are starting to appreciate the need for corporate governance mechanisms, they argue that together with Fawzy's four characteristics, weakness in the economic structure, and lack of awareness of corporate governance concepts and benefits, hinder the development of corporate governance in Egypt. Thus the results of this research may be useful for regulators in developing and emerging nations with similar characteristics as they continue to deliberate appropriate corporate governance requirements in their own nations.

In an Egyptian context, Samaha and Dahawy (2010, and 2011) found that corporate governance mechanisms affect the Egyptian companies' general printbased annual reports voluntary disclosures. They found lower directors ownership; lower block-holder ownership; higher independent directors and audit committee existence are more properly to monitor the manager's decision to report more voluntary information. Investigating the determinants of corporate governance disclosures in the 2005 annual reports of the top thirty Egyptian listed companies' (EGX 30), Samaha (2010) found that board independence is positively associated with corporate governance disclosures. This paper extends the work done by Samaha (2010) as follows: firstly, it provides a more recent investigation (year 2009) to help assess developments in corporate governance 
disclosure. Secondly, it offers a comparative analysis with two international reports on corporate governance disclosure scores conducted by the United Nation Conference on Trade and Development (UNCTAD). Thirdly, the sample companies involve the EGX 70 constitutes along with the EGX 30 constitutes and thus enhancing the generalizability of the empirical results, along with. Finally, this paper introduces a more comprehensive set of corporate governance mechanisms including board size and duality in positions that -to the best of authors' knowledge- have been not tested before in an Egyptian context in relation to corporate governance disclosure. Our descriptive findings relating to the extent of corporate governance disclosure for 2009 are relatively lower than those reported by Samaha (2010) for a sample of Egyptian firms in 2005, although during this period from 2005 to 2009, many regulation changes have taken place in Egypt such as the formation of the Egyptian Financial Supervisory Authority (EFSA), and the update of the CG code. All these changes aim to enhance CG disclosure and transparency in general; however our paper suggests that CG disclosure by listed Egyptian firms is almost negligible.

The paper is organized as follows. Section 2 provides an overview on the corporate governance in Egypt. Section 3 reviews prior research and develops the research hypotheses. Section 4 explains describes the sample, data and the research methods. Section 5 presents the results. Section 6 concludes. 


\section{The corporate governance in Egypt}

Corporate governance has many benefits for developing nations like Egypt. It helps developing nations to realize high and sustainable rates of growth, increases confidence in the national economy, and deepens capital market and increases its ability to mobilize savings. In addition, it results in raising investment rates, protecting the rights of the minority shareholders or small investors. Also, it encourages growth of private sector by supporting its competitive capabilities, helping to secure financing for projects, generating profits, and creating job opportunities (Dahawy, 2008).

In recognition of the need to enhance the level of confidence of foreign portfolio investors in the Egyptian capital market, the ministry of investment through the Egyptian Institute of Directors (EIoD) (http://www.eiod.org) introduced a corporate governance code in 2005 for companies listed in the stock market, especially those being actively trading. The Egyptian Corporate Governance Code (ECGC) is initially prepared in accordance with the Guidelines on Corporate Governance of State-Owned Enterprises in the Organization for Economic Co-operation and Development (OECD). Subsequently, a team of Egyptian experts drafted the initial code, which was then subjected to in-depth examination and extended discussions. At the end, the code was reviewed by 
experts from the OECD, the IFC (International Finance Corporation) and also the World Bank.

This code includes many provisions, the objectives of which are to guarantee the rights of all shareholders as well as various stakeholders. Enhancing corporate disclosure transparency is one of the pillars of corporate governance. The introduced ECGC searches for more accuracy of disclosed corporate information organizing the relationship between the shareholders, board of directors and management. However, compliance with the ECCG code is not mandatory.

Actual corporate governance practices of Egyptian listed companies continue to lag behind the law on the books, in particular for companies outside the EGX 30 (World Bank, 2009). For example, a number of boards do not guide or supervise management by helping them develop and holding them accountable to a set of key performance indicators. Key policies on risk management, internal control and audit processes, and succession planning are often absent. Board nomination processes largely remain opaque and are frequently dominated by majority owners, at times leading to important skills-gaps and insider boards. Although financial reporting has improved markedly in terms of the timeliness and quality of disclosure; however, non-financial disclosure remains underdeveloped. Few companies publicly disclose their ownership and governance structures, remuneration policies, or foreseeable risk factors online or in their annual reports (World Bank, 2009). 
However the corporate governance ROSC (World Bank, 2009) argued that Egypt can take a major step forward in closing these gaps by requiring companies to implement the Egyptian Corporate Governance Code (ECGC) on a 'comply-orexplain' basis, and amending the ECGC to better meet good practice and Further strengthening enforcement capacity and supporting the EIoD to roll-out its director training program, focusing on family-owned businesses outside the EGX 30.

\section{Economic Incentives and Hypotheses}

This section reviews the possible incentives for corporate governance disclosure and develops the related research hypotheses. Corporate governance mechanisms can be considered as key factors explaining the decisions of corporate voluntary disclosure from agency theory perspectives. Thus, these mechanisms will be examined in this paper. It is also worth noting that very limited research has been undertaken to examine the association between corporate governance mechanisms and corporate governance disclosure. To the best of our knowledge, only five published papers examine this research issue (two of these articles focus on the developed countries, while three focus on the developing countries). For the developed countries, using Canadian firms, Bujaki and McConomy (2002) find that firms with more unrelated directors are more likely to voluntarily disclose more corporate governance information. For a sample of European companies, Bauwhede and Willekens (2008) find that 
ownership structure affects levels of corporate governance disclosures. In the developing countries, Muhamed et al (2009) find that corporate governance mechanisms do not affect levels of corporate governance disclosure in Malaysia, while Al-Moataz and Hussainey (2010) find that board independence and audit committee size are the key incentives for corporate governance disclosures in Saudi Arabia. Samaha (2010) find that board independence affect corporate governance disclosure for a sample of 30 Egyptian companies. To develop our research hypotheses, we review prior research which suggests association between voluntary disclosure and some corporate governance mechanisms. We formulate hypotheses related to board characteristics, ownership structure and the existence of audit committees as follows.

\section{BOARD CHARACTERTICS}

\section{Board Composition}

Fama (1980) argues that the board of directors, which is elected by the shareholders, is the central internal control mechanism for monitoring managers. Fama (1980) and Fama and Jensen (1983), and more recently Chau and Leung (2006) and Weir and Laing (2003) suggest that boards with a higher proportion of outside or independent directors will increase the quality of monitoring over management, because "they are not affiliated with the company as officers or 
employees, and thus are independent representatives of the shareholders' interests" (Pincus et al. 1989: 246). Beasley (1996) found less likelihood of fraud in financial statements produced by companies with boards with higher proportions of outside directors.

The presence of independent directors on boards may improve the quality of financial statements. For example, they are associated with less earnings management (Peasnell et al., (2000); Chtourou et al., 2001; Xie et al., 2001; and Klein, 2002). Such findings may be attributable to the positive association between the number of independent directors and firms' discretionary decisions to increase the level of independence on the audit committee above the suggested minimum (Williams, 2002).

Furthermore, non-executive directors may boost monitoring of the quality of financial disclosures, as reported by Chen and Jaggi (2000) in Hong Kong and Cheng and Courtenay (2004) in Singapore. That is, they encourage more voluntary disclosures (Adams and Hossain, 1998), specifically, as reported by Leung and Horwitz (2004), in relation to voluntary segment disclosure. They reduce the benefits from withholding information (Forker, 1992) and, as Dechow et al. (1996) found, firms with boards dominated by management incur more accounting enforcement actions by the SEC. Prior research supports the positive association between voluntary disclosure and board independence (i.e. Abdelsalam and Street, 2007; Adams et al., 1998 and Chen and Jaggi (2000). On 
the other hand, other studies some researchers, especially in developing nations, do not find a significant relationship between the level of voluntary disclosure and board independence (Ghazali and Weetman (2006), Haniffa and Cooke (2002), and Ho and Wong (2001). This may be due to the ties that some non-executive directors have to the company that undermines their independence in some countries (Tengamnuay and Stapleton, 2008). Other research supports a substitute relationship. Eng and Mak (2003), Barako et al. (2006), and Gul and Leung (2004) report a significant negative association between the level of voluntary disclosure and board independence. Al-Moataz and Hussainey (2010) also find a negative association between corporate governance voluntary disclosures and board independence in Saudi Arabia.

In the Egyptian context, Ezat and El-Masry (2008) and Samaha and Dahawy (2010 and 2011) find that the association between board independence and voluntary disclosure in Egypt is positive. Based on these arguments, we set our first hypothesis as follows:

H1 Companies with higher proportions of independent non-executive directors on the board have higher levels of CG disclosures.

Board Size 
Board size is the number of executive and non-executive directors on company's board. Agency theory suggests that large boards can play a crucial role in monitoring the board and in making strategic decisions. In addition, it suggests that large boards are less likely to dominant by the management (Hussainey and Wang, 2011). Furthermore, large boards lead to increase the expertise diversity in the board including financial reporting expertise (Singh et al, 2004; Yermack, 1996; Laksamana, 2008). Prior research also find that there is a negative association between board size and earnings management, suggesting that large board size leads to higher disclosure quality. Therefore, firms with large board size are more likely to voluntarily disclose more information in their annual reports and websites.

On the other hand, Goodstein et al (1994) argue that large board size might have a negative effect of the effectiveness of the board. Members of large boards are more likely to be less motivated to participate in strategic decision-making (i.e. the decision to increase voluntary disclosure). As a result, a negative association between board size and disclosure would be expected.

Majority of prior studies find a positive association between board size and voluntary disclosure (Barako et al, 2006; Laksamana 2008, Hussainey and AlNajjar (2011). On the other hand, some studies did not find any association between board size and disclosure (Evans, 2004; Willekens et al, 2005; Lakhal, 2005). 
In the Egyptian context, Ezat and El-Masry (2008) find that board size is positively associated with levels of corporate voluntary disclosure. Based on these arguments, we set our second hypothesis as follows:

H2 Companies with large board size have a higher level of CG disclosure.

\section{Duality in position}

Role duality in position exists when the CEO (Chief executive officer) is also the chairman of the board at the same time. Agency theory predicts that role duality creates individual power for CEO that would affect the effective control exercised by the board. Fama (1980) and Fama and Jensen (1983) argue that independent directors can play a significant role in monitoring the performance of managers and limit their earnings management. In addition, Gul and Leung (2004) argue that firms with large number of independent directors are expected to be more effective in board monitoring and hence in offering more information to the public.

Prior research on the association between duality in position and corporate voluntary disclosure is mixed. Some studies find a negative association between the two variables (Lakhal, 2005; Laksamana, 2008; Forker, 1992, Haniffa and Cooke, 2002; Eng and Mak, 2003; Gul and Leung, 2004). Other studies did not 
find any significant association between the two variables (Arcay and Vazquez, 2005; Cheng and Courtenay, 2006; Ho and Wong, 2001; Ghazali and Weetman, 2006). In the Egyptian context, Ezat and El-Masry (2008) find that duality in position is negatively associated with levels of corporate voluntary disclosures, but the association is not statistically significant at an acceptable level. Based on these arguments, we set our third hypothesis as follows:

H3 Companies with duality in position have a lower level of CG disclosures.

\section{OWNERSHIP STRUCTURE}

Agency theory suggests that companies will disclose more information where there is diffused ownership (Jensen and Meckling, 1976). Compared to companies with concentrated ownership, there is greater potential for agency conflict with diffuse ownership since the divergence of interests between the contracting parties is likely to be wider. Disclosure may reduce agency costs since it helps solve the monitoring problems experienced by diffuse owners (Schipper, 1981). Haniffa and Cooke (2002) argue that the structure of ownership determines the level of monitoring and thereby the level of disclosure, so that in a widely-held company, managers may provide additional information to signal that they are acting in the best interests of the principles, whereas highly concentrated ownership may be linked to lower levels of disclosure. 
The current paper uses three ownership measures: director ownership (the proportion of ordinary shares held by the CEO and executive directors), blockholder ownership (the proportion of ordinary shares held by substantial shareholders with shareholdings of $5 \%$ or more) and the number of shareholders.

\section{Director ownership}

A director who owns a substantial portion of the company's shares bears the consequences and reaps the benefits of managerial actions that destroy and create value; thus, agency costs may be reduced by director ownership (Jensen and Meckling 1976), because it aligns the interests of the agent and shareholder, thereby reducing the need for shareholder monitoring and thus disclosure.

Low director ownership increases agency problems because managers have greater incentives to consume bonuses and lower incentives to maximize job performance (Eng \& Mak, 2003), so that, shareholders need to counteract the increase in agency costs (Ghazali \& Weetman, 2006). However, as additional monitoring increases the costs of the firm managers have an incentive to provide voluntary disclosures (Eng \& Mak, 2003). That is, disclosure is a substitute for monitoring. Furthermore, Kelton and Yang (2008) predict that the need for more monitoring and more transparent disclosure decreases with higher percentages of director ownership, so that, director ownership is a corporate governance mechanism that acts as a substitute for disclosure. 
Early empirical evidence supports these arguments in developed nations, for example Ruland et al. (1990) show director ownership to be negatively related to voluntary disclosure. In developing countries, for example, Eng and Mak (2003) find such an association in Singapore listed companies, as do Ghazali \& Weetman (2006) in Malaysian companies.

In an Egyptian context, Samaha and Dahawy (2011) find a negative association between the director ownership and the voluntary corporate disclosures made by the top 30 Egyptian listed companies. Based on these arguments, we set our fourth hypothesis as follows:

H4 Companies with low percentages of director ownership have higher levels of CG disclosures.

\section{Block-holder ownership}

Block-holder is a shareholder with an exceptionally large amount of shares. Early research indicated the presence of a negative relation between block-holder ownership and disclosure in developed countries such as Australia (McKinnon and Dalimunthe, 1993; and Mitchell et al., 1995), Finland (Schadewitz and Blevins, 1998), and Germany (Marston and Polei, 2004). Mixed results were found in developing countries. In a Malaysian context, for example, Hossain et al (1994) find a negative association between voluntary disclosure and block-holder ownership, while Haniffa and Cooke, (2002) find a positive association. Marston and Polei (2004) argue that investors who own only a small percentage of shares 
in a company have limited access to information about the company. Therefore, it is likely that firms with a more dispersed ownership of shares will disclose more information to satisfy investors' needs. In contrast, investors with large equity shares in a company can obtain information about the company from internal sources. Therefore, more closely held companies are more likely to disclose less information because their large investors can access internal sources of information.

In an Egyptian context, the findings of Samaha and Dahawy (2010 and 2011) indicate a negative impact for block-holder ownership on voluntary corporate disclosures. Based on these arguments, we set our fifth hypothesis as follows:

H5 Companies with lower percentages of block-holder ownership have higher levels of $C G$ disclosures.

\section{Number of shareholders}

Based on the agency theory, García-Meca and Sánchez-Ballestabas (2010) argue that information asymmetry between companies and their shareholders increases when ownership is widely dispersed. Therefore, the existence of a higher number of shareholders for a company would increase agency costs. To reduce these costs, firms are more likely to voluntarily disclose more information in their annual reports and/or websites. Prior research, mostly addressing 
voluntary disclosures in general, supports the agency theory hypothesis that levels of disclosure are positively associated with numbers of shareholders in different countries such as Sweden (Cooke, 1989); USA (Malone et al., 1993), Japan, (Cooke, 1991) and Hong Kong and Singapore (Chau and Gray, 2002). In an Egyptian context, Samaha and Dahawy (2010 and 2011) did not find any evidence for an association between number of shareholders and the corporate voluntary disclosure level. Based on these arguments, we set our sixth hypothesis as follows:

H6 Companies with greater numbers of shareholders have higher levels of corporate governance $(C G)$ disclosures.

\section{AUDIT COMMITTEE}

Historically audit committees were a monitoring mechanism formed voluntarily in high agency cost situations to improve the quality of information flow between principal and agents (Bradbury, 1990). The 1980s and 1990s saw substantial growth in the numbers of audit committees often as a response to financial scandal, and they have received increased awareness in recent years (Mangena and Tauringana, 2008). Agency theory predicts that audit committees should lower agency costs especially if, following best international practice, they consist mainly of non-executive directors. Audit committees may be an important 
part of the decision control system used by the board of directors to monitor internal control (Fama, 1980), and predicted benefits include ensuring the quality of financial accounting and control systems (Collier, 1993).

Empirical evidence suggests that audit committees play a complementary role to information disclosure (Forker, 1992; Barako et al., 2006). The Egyptian context empirical results are mixed; Samaha and Dahawy (2010 and 2011) found an audit committee existence complementary effect on the general corporate voluntary disclosures; however Samaha (2010) did not find a significant association with the Egyptian corporate governance disclosures. Based on these arguments, we set our seventh hypothesis as follows:

\section{H7 Companies with audit committees have a higher level of CG disclosure}

\section{Research Method}

\section{Sample and data}

The study examines annual reports and websites of the most active 100 Egyptian companies on the Egyptian Stock Exchange as measured by the EGX 100 index at the financial year ends on 2009. The CG disclosure data were measured using a content analysis technique. Data on explanatory variables were found either on the annual reports or on the companies' websites. We limit our analysis to 100 companies due to the fact that measuring corporate disclosure 
levels by the traditional content analysis requires a considerable time and effort. The sample included the hard copy annual reports for 2009, as well as current CG disclosures on the companies' websites. As a starting point we examined official company websites in order to get information concerning the annual reports for 2009, internet reporting and any CG stand-alone reports for 2009. Annual reports and corporate governance data are purchased from the Egyptian Company for Information Dissemination (EGID) in case the company did not have a website or did not provide its annual report on the website. Firm characteristics data such as leverage, firm size, profitability and industry types are collected from firms' annual reports or websites. ${ }^{1}$

The study uses a corporate governance checklist developed by the Intergovernmental Working Group of Experts on International Standards of Accounting and Reporting (ISAR) that is organized by UNCTAD. The checklist follows ISAR's good guidance practice (ISAR, 2006), which has become its benchmark for conducting the content analysis for the annual reports and websites to identify corporate governance disclosure score for our sample.

Table 1 presents the definition of our dependent variable and the definitions and the source of information for each independent variable.

Insert Table 1 here 


\section{Model specification and variable measurement}

To test for an association between CG disclosure levels and CG attributes in Egypt, one overall (EXTCGDIS) and five sub-indices, corresponding to the five UNCTAD categories, have been calculated. The dependent variables are listed and defined in Table 6 Panel A. The scores for the overall and sub-indices are calculated by assigning equal weightings to each item of disclosure, and the indices were derived by computing the ratio of actual scores awarded to the maximum possible score attainable for items that were applicable to each company.

Each item of disclosure was scored without a weighting on a dichotomous basis taking the commonly used approach of giving the item a score of 1,0 , or not applicable N/A (see for example, Ghazali and Weetman, 2006; Chau and Gray, 2002; Cooke, 1989, 1991; Haniffa and Cooke, 2002; and Ho and Wong, 2001). To ensure that companies were not penalized for non-disclosure of irrelevant items each annual report (hard copy or on the companies' websites) was read in its entirety, following Cooke $(1989,1991)$. Furthermore, all annual reports (hard copy or on the companies' websites) were read twice to ensure consistency in scoring. The second examination was done after analyzing all annual reports in the first round to ensure consistency in scoring. In the few cases where differences existed between the first and second scoring, the annual reports (hard copy or on 
the companies' websites) were subjected to a third final assessment. We use the following OLS transformed multiple regression model ${ }^{2}$ :

$\boldsymbol{E X T C G D I S}=\beta 0+\beta 1 \mathrm{BCOM}+\beta 2 \mathrm{BSIZE}+\beta 3 \mathrm{DUAL}+\beta 4 \mathrm{DIR}+\beta 5 \mathrm{BLK}+$ $\beta 6 \mathrm{NS}+\beta 7 \mathrm{ACO}+\beta 8 \mathrm{LVG}+\beta 9 \mathrm{LGSIZE}+\beta 10 \mathrm{PRO}+\beta 11 \mathrm{INDT}+\mathrm{e}$

We also use the following regression models to examine the association between corporate governance voluntary disclosure sub-categories and corporate governance mechanisms. We use the transformed OLS multiple regression for the following subcategories of corporate governance disclosure (OSE; FT and BM):

$\boldsymbol{O S E}=\beta 0+\beta 1 \mathrm{BCOM}+\beta 2 \mathrm{BOSIZE}+\beta 3 \mathrm{DUALT}+\beta 4 \mathrm{DIR}+\beta 5 \mathrm{BLK}+\beta 6 \mathrm{NS}$ $+\beta 7 \mathrm{ACO}+\beta 8 \mathrm{LVG}+\beta 9 \mathrm{LGSIZE}+\beta 10 \mathrm{PRO}+\beta 11 \mathrm{INDT}+\mathrm{e}$

$\boldsymbol{F T}=\beta 0+\beta 1 \mathrm{BCOM}+\beta 2 \mathrm{BOSIZE}+\beta 3 \mathrm{DUALT}+\beta 4 \mathrm{DIR}+\beta 5 \mathrm{BLK}+\beta 6 \mathrm{NS}+$ $\beta 7 \mathrm{ACO}+\beta 8 \mathrm{LVG}+\beta 9 \mathrm{LGSIZE}+\beta 10 \mathrm{PRO}+\beta 11 \mathrm{INDT}+\mathrm{e}$

$\boldsymbol{B M}=\beta 0+\beta 1 \mathrm{BCOM}+\beta 2 \mathrm{BOSIZE}+\beta 3 \mathrm{DUALT}+\beta 4 \mathrm{DIR}+\beta 5 \mathrm{BLK}+\beta 6 \mathrm{NS}$ $+\beta 7 \mathrm{ACO}+\beta 8 \mathrm{LVG}+\beta 9 \mathrm{LGSIZE}+\beta 10 \mathrm{PRO}+\beta 11 \mathrm{INDT}+\mathrm{e}$ 
We also use a binary logistic regression model for the CR subcategory of corporate governance disclosure. We use the following model:

$\boldsymbol{C} \boldsymbol{R}=\beta 0+\beta 1 \mathrm{BCOM}+\beta 2 \mathrm{BOSIZE}+\beta 3 \mathrm{DUALT}+\beta 4 \mathrm{DIR}+\beta 5 \mathrm{BLK}+\beta 6 \mathrm{NS}$

$+\beta 7 \mathrm{ACO}+\beta 8 \mathrm{LVG}+\beta 9 \mathrm{LGSIZE}+\beta 10 \mathrm{PRO}+\beta 11 \mathrm{INDT}+\mathrm{e}$

For the Audit subcategory of corporate governance voluntary disclosure, we could not run the model as this subcategory was scored zero by more than $95 \%$ of the sample companies and hence there were not enough variations among the sample companies.

\section{Empirical results}

\section{Descriptive analysis}

The ISAR checklist examines a total of 53 corporate governance disclosure items, which are normally divided into five categories. For each of these five categories, Table 2 presents, in the first column, the corporate governance disclosures achieved by the top 100 Egyptian companies, together with comparison figures that show that these disclosure levels are typically lower than those reported by UNCTAD (2006) in its annual international review. The second column of the table shows the disclosures made by 105 enterprises drawn from both high and low/middle income countries and the third columns show a comparison with 63 enterprises drawn from low/ middle income countries only. 
Panel 1 shows that in line with international experience all 100 companies disclose the company objectives, and financial and operating results, and that at least two thirds make disclosures about accounting estimates and related party transactions. These three financial transparency items are required by Egyptian Accounting Standards (EASs). Panel 2 shows that the degree of disclosure relating to $O S E$ is low by international standards, with even the best items attracting only a 37\% implementation rate. As Panel 3 shows, by far the most frequent disclosures relating to $B M$ in Egypt are "risk management objectives, system and activities". Again this is an area of mandatory reporting under EASs.

In line with international experience $C R$ and auditing related disclosures are the lowest. Nevertheless, as shown in Panel 4 just short of 10\% of Egyptian companies do make some environmental and social responsibility disclosures. Least disclosure was evident in the auditing category in Egypt, as Panel 5 shows, and in this context it is worth noting that Egypt does not have rules similar to those in the US Sarbanes Oxley Act which prohibit accounting/auditing firms from simultaneously providing both auditing and consulting services to the same client.

Insert Table 2 here 
The descriptive statistics for the independent variables are shown in Table 3. The average firm size in terms of total assets is 3.7 billion Egyptian pounds (approximately 462 million Euros). The debt: equity (leverage) ratio is on average $57 \%$ and there are an average of 17 shareholders, implying that the ownership structure is quite highly geared and highly concentrated in these companies, although there are quite wide distributions in the values of the total assets and the number of shareholders. On average profitability (PRO) indicates that majority of firms are profitable. The mean percentage of independent directors on the board is $56 \%$. Average board size is 11 members. Mean director ownership is $9 \%$. Twenty two percent of the chosen sample has an audit committee; $61 \%$ of company's CEO serves as a board chairman and $55 \%$ of our chosen firms are related to manufacturing industry.

Insert Table 3 here

Table 4 shows the distribution of the dependent variable. Panel 1 shows that while there are large variations among the sample companies, these indices and their ranges suggest that the overall disclosure level is relatively low, implying that, consistent with Ho and Wong (2001) in Hong Kong, analysts in Egypt may need to search for information outside of the published annual reports. Panel 2 shows the distribution of five sub-indices of information. On average, as in other 
countries the Egyptian companies perform best on $F T$, where they provide $50.4 \%$ of the items. It is worth noting that Egyptian Accounting Standards require disclosure of five of the nine items in this sub-index and disclosure is checked by the newly formed Egyptian Financial Supervisory Board (EFSA) (http://www.efsa.gov.eg/). Failure to disclose results in a warning letter and ultimately could lead to delisting. Disclosure of items in the other four subindices, which are generally not required by EASs or followed by the EFSA, are, on average, all below $40 \%$.

Insert Table 4 here

\section{Correlation analysis}

Table 5 presents the correlation analysis between the overall corporate governance voluntary disclosure and independent variables. It shows that firms with higher number of shares; large number of independent directors on boards and firms with large size are more likely to provide higher levels of corporate governance voluntary disclosures. It shows that EXTCGDIS is positively correlated with NS $(r=.482)$, BCOM $(r=.496)$ and LGSIZE $(r=.547)$ and these correlations are statistically significant at the $1 \%$ level. The table also shows that firms with large block holder ownership and role duality are more likely to provide less corporate governance voluntary disclosures. It shows that 
EXTCGDIS is negatively correlated with block-holder ownership (BLK) (r =.577) role duality (DUALT) $(\mathrm{r}=-.620)$ and these correlations are statistically significant at the $1 \%$ level. Thus the univariate analysis supports $\mathrm{H} 6$ and $\mathrm{H} 1$ that the number of shareholders and proportion of independent directors are positively correlated with the level of corporate governance disclosure. H5 and H3 are also supported because block-holder ownership and role duality dual is negatively correlated with the level of disclosure. However, neither the correlation between DIR and EXTCGDIS nor BOSIZE and EXTCGDIS is significant, so that hypotheses $\mathrm{H} 2$ and $\mathrm{H} 4$ are not supported.

Insert Table 5 here

\section{Regression results}

Regression results are shown in Tables 6 and 7. Table 6 shows the crosssectional OLS regressions for the aggregated score of corporate governance voluntary disclosures score and three sub-categories (OSE; FT and BM), Table 7 shows the cross-sectional binary logistic regressions for CR subcategory.

For the board composition, we find that the coefficient estimate on BCOM is positive and statistically significant with EXTCGDIS at the $1 \%$ level. This supports hypothesis $\mathrm{H} 1$ that companies with a higher proportion of independent directors on the board disclose more CG information in their annual reports. 
Furthermore, the coefficient estimates on the proportion of independent directors on the board are positive and significant at the 5\% level in explaining two types of CG disclosure (OSE and FT). This finding is consistent with the Egyptian studies of Samaha and Dahawy (2010 and 2011) and Samaha (2010).

We find that the coefficient estimates on board size are mixed (positive and negative) and is not statistically significant in any of the corporate governance disclosure models. Therefore we reject $\mathrm{H} 2$. These findings are in line with prior research (i.e. Evans, 2004; Willekens et al, 2005; Lakhal, 2005).

We find that the coefficient estimates on role duality are negative and statistically significant for EXTCGDIS, OSE and BM. The negative sign on role duality is consistent with prior research (i.e. Lakhal, 2005; Laksamana, 2008; Forker, 1992, Haniffa and Cooke, 2002; Eng and Mak, 2003; Gul and Leung, 2004, Ezat and El-Masry). Therefore we partially accept H3.

Furthermore, director ownership is negatively associated with only one category of CG disclosure (CR), so that hypothesis $\mathrm{H} 4$ that $\mathrm{CG}$ disclosure increases with decreases in director ownership is not generally supported.

As we find significant negative association between BLK and EXTCGDIS, OSE, BM and CR, hypothesis H5 is partially accepted. This finding for Egyptianlisted companies is line with Samaha and Dahawy (2010 and 2011) and consistent with prior research in developed (i.e. Martson and Polei, 2004) and developing (i.e. Hossain et al, 1994) countries who also found that the level of voluntary 
disclosure is significantly related with block-holder ownership. Our sixth hypothesis predicts that ownership structure is associated with overall CG disclosure, as well as the various subcategories of information. With respect to the number of shareholders we do not find any significant association between NS and EXTCGDIS, OSE, FT, BM or CR, which indicates that ownership structure is not influencing of CG disclosures in Egypt. Thus, hypothesis H6 is rejected. Our results are consistent with Ghazali and Weetman (2006) found ownership structure is not statistically significant in explaining voluntary disclosure in Malaysia.

Our findings in relation to the existence of an audit committee (ACO) suggest that in order to understand the drivers of $\mathrm{CG}$ disclosure research should disaggregate the dimensions of $\mathrm{CG}$. $\mathrm{ACO}$ is neither significant in explaining overall CG disclosure nor three of the four partial categories of CG disclosure indicating a lack of support for hypothesis $\mathrm{H} 7$. We only find a significant positive association between ACO and the CR model $(\mathrm{p}<.065)$. This is a predicted direction which is consistent with Ho and Wong (2001) and Barako et al. (2006) who found the existence of audit committees to be positively significant. This may suggest that audit committees in Egypt play a complementary monitoring role to CR CG disclosure. This finding is line with Samaha and Dahawy (2010 and 2011) in regards to the print-based (hard copy) annual reports voluntary 
disclosures, however inconsistent with Samaha's (2010) corporate governance disclosures analysis.

In relation to our control variables, we find that leverage is not statistically significant in any of the corporate governance disclosure models. This implies that the level of corporate governance disclosure is not influenced by the agency costs of debt in Egypt. We also find a positive association between firm size and EXTCGDIS, FT and BM at the $1 \%$ level. It is usually expected that larger firms arrange for voluntary disclosure more often than smaller ones. This seems reasonable because of financial facilities and benefiting from stronger information systems. Profitability and industry type are only significant in explaining one type of CG information (CR). The coefficient estimates on both variables are positive and significant at the $10 \%$ level.

\section{Conclusions}

The association between corporate governance mechanisms and corporate disclosure has been examined over the last few years. However, limited studies examine the extent to which corporate governance mechanisms affect firms' decisions to voluntarily report corporate governance information in their annual reports. This paper extends and contributes to recent governance and disclosure literature (i.e. Samaha, 2010) by offering empirical evidence on the impact of a 
comprehensive set of corporate governance variables on corporate governance voluntary disclosure for a large sample of most and less actively traded companies in Egypt, as an example of an emerging economy.

In terms of overall disclosure practice, we find that there are generally low levels of disclosure, except for the items which represent mandatory disclosure as required by Egyptian Accounting Standards. It is interesting to note that in total 41 of the 53 items in the checklist are mandatory because of EGX listing requirements (UNCTAD, 2007), but that levels of disclosure are low on many of the items which EGX requires but EAS does not. This does suggest that enforcement of EGX rules requires tightening. Our descriptive findings on the extent of CG disclosure relating to the year 2009 are relatively similar to Samaha (2010) for a sample of listed Egyptian companies in 2005. The failure of companies to disclose such information clearly shows some ineffectiveness and inadequacy in the regulatory framework in Egypt. Moreover, the phenomenon of non-compliance may also be attributed to the socio-economic factors in Egypt. Given the present unbalanced political situation, prevalent corruption, deteriorating law and order situation and the influence of the social elite, noncompliance to the legal requirements often go unpunished encouraging more noncompliance. Furthermore, this may imply that the learning curve is very slow in developing countries compared to developed countries. In the absence of independent verification, the credibility of $\mathrm{CG}$ information disclosed is 
questionable. To sum up, the reasons for this phenomenon may be attributed to the lack of statutory CG disclosure requirements, less CG awareness, an underdeveloped corporate culture and the relatively new stock market which was activated in the mid 1990's. In light of the above, it is expected that firms will take a long time to appraise the payback of increased CG disclosure.

Regarding the determinants of corporate governance disclosures, we find that ceteris paribus - the extent of CG disclosure of Egyptian-listed companies: (1) is lower for companies with duality in position and higher ownership concentration as measured by block-holder ownership; and (2) increases with the proportion of independent directors on the board and the firm size. By disaggregating total CG disclosure into the 4 UNCTAD components, we are able to also specify the components of CG impacted by various determinants.

This paper is also subject to a number of limitations. First, we are mainly testing hypotheses on the potential incentives of disclosure on corporate governance that are particularly well grounded in uses of governance in developed countries, but less so in developing environments. In particular, our hypotheses are mainly relating to agency and information asymmetry problems stemming from the relationship between the firm and its external financiers (shareholders or debtholders). A worthwhile avenue for future research could be to test additional hypotheses of the demand for corporate governance disclosure 
originating from other stakeholders than just shareholders or debtholders. Second, our analysis is limited to a sample of Egyptian companies. However, we believe that the same hypotheses are worth testing outside Egypt, and that it is reasonable to expect a higher level of corporate governance disclosure in other countries with better investor protection and with more developed capital markets.

Despite the limitations, the results of the study support theoretical arguments that companies disclose corporate governance information in order to reduce information asymmetry and agency costs stemming from the separation between ownership and control, and to improve investor confidence in the reported accounting information.

It is interesting to consider the costs and benefits of the reform processes that Egypt and other countries are implementing. While the ECGC recommends that actively traded companies should have an audit committee and exploit the knowledge of independent board members, the findings of this study indicate that only three of these new provisions to enhance corporate governance (block-holder ownership; independent directors; role duality) are statistically significant in explaining CG disclosure in Egyptian annual reports. However, this study shows that audit committees' role in Egypt does not comply with the fundamentals of agency theory and that this CG supervisory tool has little role in improved financial disclosure. That is the benefit of audit committees is unclear. This would 
be an interesting idea for further research. In addition, it would be interesting to examine the stock market reaction to the aggregated and different types of corporate governance disclosures. 


\section{Corporate Governance Disclosure And Its Determinants In Egypt}

\section{NOTES}

${ }^{1}$ The extant literature identifies several company-specific characteristics as relevant to the voluntary disclosure of financial information. Some variables such as company size are generally found to be significant in prior literature, perhaps because they are politically visible, more exposed to greater regulation, such as price controls, and possibly the threat of nationalization. Therefore, they disclose more information (Eng and Mak, 2003). With respect to other variables, the results are inconsistent across studies, often depending on country and exchange studied. Thus the choice of control variables in the multiple regression models for testing the main hypotheses, shown in Table 1 Panel C, follows the practice in prior research (see for example: Raffournier, 1995; Meek et al., 1995; Ho and Wong, 2001; Eng and Mak, 2003; Ghazali and Weetman, 2006 and Aly et al, 2010).

${ }^{2}$ A multicollinearity test was performed using Pearson's product moment correlations. Our analysis shows that there is no multicollinearity problem between the independent variables. Regression diagnostics were also performed to determine if the assumptions of normality and equal variances were met for all dependent variables. Diagnostics included Q-Q normality plots, examination of histograms of all dependent variables, scatter plots of residuals against the predicted values, and the Kolmogorov-Smirnov Z-test with Lilliefors correction for each independent and dependent variable. This test for each independent and dependent variable indicated that some of the corporate governance independent variables are not normally distributed. Thus, following Cooke (1998), the continuous independent and dependent variables were transformed into ranks based on normal scores before running the regression analysis. 


\section{REFERENCES}

Abdelsalam, O.H. and Street, D.L. (2007), 'Corporate governance and the timeliness of corporate internet reporting by UK listed companies', Journal of International Accounting, Auditing and Taxation, Vol. 16, pp. 111-30.

Adams, M., and Hossain, M. (1998). 'Managerial discretion and voluntary disclosure: Evidence from the New Zealand life insurance industry', Journal of Accounting and Public Policy, 17, 245-281.

Adams, C., Hill, W.Y. and Roberts, C.B. (1998), 'Corporate social reporting practices in Western Europe: legitimation corporate behaviour', British Accounting Review, Vol. 30, pp. 1-21.

Ahunwan, B. (2002). “Corporate governance in Nigeria." Journal of Business Ethics, Vol. 37(3) pp. 269-287.

Al-Moataz, E and Hussainey, K. (2010). Determinants of corporate governance disclosure in Saudi companies, Journal of Economics and Management, University of King Abdul Aziz, forthcoming.

Aly, D., Simon, J. and Hussainey, K. (2010). 'Determinants of corporate internet reporting: evidence from Egypt'. Managerial Auditing Journal, 25 (2): 182202. 
Arcay, R.; and Vazquez, F., (2005) “Corporate Characteristics, Governance Rules and the Extent of Voluntary Disclosure In Spain", Advances in Accounting, 21, pp 299-331.

Barako, D.G., Hancock, P., and Izan, H.Y. (2006). 'Relationship between corporate governance attributes and voluntary disclosures in annual reports: The Kenyan experience', Financial Reporting, Regulation and Governance, 5:1, pp: 1-25.

Bauwhede, H. V. and Willekens, M. (2008). Disclosure on corporate governance in the European Union, Corporate Governance: An International Review, 16(2), 101-115.

Beasly, M.S. (1996). 'An empirical analysis of the relation between the board of director composition and financial statement fraud', The Accounting Review, Vol. 71, pp: 443-465.

Bhuiyan, M.H.U. and Biswas, P.K. (2007) ' Corporate governance and reporting: An empirical study of the listed companies in Bangladesh', Journal of Business Studies, Vol. XXVIII, No. 1, pp 1-32.

Bradbury, M. E. (1990). 'The incentives for voluntary audit committee formation', Journal of Accounting and Public Policy, Vol. 9, pp: 19-36.

Bremer, J., and Ellias, N. (2007). "Corporate governance in developing economies -The case of Egypt." International Journal of Business Governance and Ethics, Vol. 3(4) pp. 430-445. 
Bujaki, M. and McConomy, B. (2002). Corporate governance: Factors influencing voluntary disclosure by publicly traded Canadian firms. Canadian Accounting Perspectives, 29(1): 105-139.

Chau, G., and Leung, P. (2006). 'The impact of board composition and family ownership on audit committee formation: Evidence from Hong Kong', Journal of International Accounting, Auditing and Taxation, Vol. 15, pp: 1-15.

Chau, G.K., and Gray, S.J. (2002). 'Ownership structure and corporate voluntary disclosure in Hong Kong and Singapore', The International Journal of Accounting, Vol. 37, pp: 247-265.

Chen, C.J.P., and Jaggi, B. (2000). 'Association between independent nonexecutive directors, family control and financial disclosures in Hong Kong', Journal of Accounting and Public Policy, Vol. 19, pp: 285-310.

Cheng, E.C.M., and Courtenay, S.M. (2004). 'Board composition, regulatory regime and voluntary Disclosure', Working paper, Nanyang Business School, Nanyang Technological University, Singapore.

Chtourou, S.M., Bedard, J. and Courteau, L. (2001). 'Corporate governance and earnings management', Working paper, Universite Laval, Canada.

Collier, P. (1993). 'Factors affecting the formation of audit committees in major UK listed companies', Accounting and Business Research, Vol. 23, pp: 421430. 
Cooke, T.E. (1989). 'Voluntary corporate disclosure by Swedish companies', Journal of International Financial Management and Accounting, Vol. 1, Issue 2, pp: 171-195.

Cooke, T.E. (1991). 'An assessment of voluntary disclosure in the annual reports of Japanese corporations', The International Journal of Accounting, Vol. 26, Issue 3, pp: 174-189.

Cooke, T.E. (1998). 'Regression analysis in accounting disclosure studies', Accounting and Business Research, Vol. 28, Issue 3, pp: 209-224.

Dechow, P.M., Sloan, R.G., Sweeney, A.P. (1996). 'Causes and consequences of earnings manipulation: An analysis of firms subject to enforcement actions by the SEC', Contemporary Accounting Research, Vol. 13, pp: 1-36.

Eng, L.L. and Mak, Y.T. (2003). 'Corporate governance and voluntary disclosure', Journal of Accounting and Public Policy, Vol. 22, pp: 325-345.

Euromoney.(2007). "The track record of corporate governance in the Middle East.” Vol. 38(September) pp 11-12.

Evans, M. (2004). Board Characteristics, Firm Ownership and Voluntary Disclosure. (Working Paper, Fuqua School of Business, Duke University).

Ezat, A and El-Masry, A. (2008). 'The impact of corporate governance on the timeliness of corporate internet reporting by Egyptian listed companies' Managerial Finance, Vol. 34 Iss: 12, pp.848 - 867 
Fama, E.F. (1980). 'Agency problems and the theory of the firm', Journal of Political Economy, Vol. 88, pp: 88-307.

Fama, E.F. and Jensen, M.C. (1983). 'Separation of ownership and control', Journal of Law and Economics, Vol. 26, Issue 2: pp: 301-326 (June).

Fawzy, S. (2004). “ How does corporate governance in Egypt compare with selected MENA and emerging markets?.” The Egyptian Center for Educational Studies, Cairo University, June.

Forker, J.J. (1992). 'Corporate governance and disclosure quality', Accounting and Business Research, Vol. 22, pp: 111-124.

Garcia-Meca and Sanchez-Ballestabes (2010). 'The association of board independence and ownership concentration with voluntary disclosure: A metaanalysis' European Accounting Review, 19(3): 603-627.

Ghazali, N.A.M., and Weetman, P. (2006). 'Perpetuating traditional influences: Voluntary disclosure in Malaysia following the economic crises', Journal of International Accounting, Auditing and Taxation, Vol. 15, pp; 226-248.

Goodstein, J., Gautam, K., and Boeker, W., (1994), "The effects of board size and diversity on strategic change”, Strategic Management Journal, 15 (3) 241-250.

Gugler, K., Mueller, D., and Burcin, Y. (2003). "The impact of corporate governance on investment returns in developed and developing nations." Economic Journal. Vol. 113(491) pp. 511-539. 
Gul, F.A., and Leung, S. (2004). 'Board leadership, outside directors' expertise and voluntary corporate disclosures', Journal of Accounting and Public Policy, Vol. 23, pp: 1-2

Haniffa, R.M., and Cooke, T.E. (2002). 'Culture, corporate governance and disclosure in Malaysian corporations', Abacus, Vol. 38, pp: 317-349.

Ho, S.M.S., and Wong, K.R. (2001). 'A study of the relationship between corporate governance structures and the extent of voluntary disclosure', Journal of International Accounting, Auditing and Taxation, Vol. 10, pp: 139156.

Hossain, M., Tan, M.L, Adams, M.B., (1994) "Voluntary disclosure in an emerging capital market: Some empirical evidence from companies listed on the KLSE". The International Journal of Accounting, 29 (4): 334-351

Hussainey, K., Al-Najjar, B., (2010). Future-oriented narrative reporting: Determinates and use. Journal of Applied Accounting Research, forthcoming.

Hussainey, K. and Wang, M. (2010). Voluntary disclosure and corporate governance: further UK evidence, Working paper, Stirling University.

ISAR (2006) ISAR Guidance on Good Practice in Corporate Governance Disclosures, available at http://www.unctad.org/en/dosc/iteteb20063_en.pdf.

Jensen, M.C., and Meckling, W.H. (1976). 'Theory of the firm: managerial behavior, agency costs and ownership structure', Journal of Financial Economics, Vol. 3, No. 3, pp: 305-360. 
Kelton, A.S., and Yang, Y. (2008). "The impact of corporate governance on internet financial reporting", Journal of Accounting and Public Policy, Vol. 27, pp: $62-87$.

Klein, A. (2002). 'Audit committee, board of director characteristics, and earnings management', Journal of Accounting and Economics, Vol. 33, pp: 375-400.

Lakhal, F. (2005). Voluntary earnings disclosures and corporate governance: evidence from France. Review of Accounting and Finance, 4(3), 64-85.

Leung, S. and Horwitz, B. (2004). 'Director ownership and voluntary segment disclosure: Hong Kong evidence', Journal of International Financial Management and Accounting, Vol. 15, pp: 235-260.

Malone, D., Fries, C. and Jones, T. (1993). 'An empirical investigation of the extent of corporate financial disclosure in the Oil and Gas industry', Journal of Accounting, Auditing and Finance, Vol. 8, No. 3: pp: 249-273 (Summer).

Mangena, M., and Tauringana, V. (2008). 'Audit committees and voluntary external auditor involvement in UK interim reporting', International Journal of Auditing, Vol. 12, Issue 1, pp: 45-63.

Marston, C.., and Polei, A. (2004). "Corporate reporting on the internet by German companies", International Journal of Accounting Information Systems", Vol. 5, pp: 285-311. 
McKinnon, J.L. and Dalimunthe, L. (1993). "Voluntary disclosure of segment information by Australian diversified companies", Accounting and Finance, Vol. 33, Issue 1: 33-50 (May).

Meek, G.K., Roberts, C.B., and Gray, S.J. (1995). 'Factors influencing voluntary annual report disclosures by U.S., U.K. and Continental European multinational corporations', Journal of International Business Studies, Vol. 26, No. 3, pp: 555-572.

Mensah, S. (2002). "Corporate governance in Ghana: Issues and challenges." Paper presented at African Capital Markets Conference, December.

Mitchell, J.D., Chia, C.W.L., Loh, A.S., (1995). 'Voluntary disclosure of segment information: Further Australian evidence', Accounting and Finance, Vol. 35, No. 2, pp: 1-16.

Muhamad, R., Shahimi, S., Yahya, Y. and Mahzan, N. (2009). Disclosure quality on governance issues in annual reports of Malaysian PLCs, International Business Research, 2(4), 61-72.

Peasnell, K.V., Pope, P.F. and Young, S. (2000). 'Board monitoring and earnings management: Do outside directors influence abnormal accruals?', Working paper, Lancaster University.

Pincus, K., Rusbarsky, M.,and Wong, J. (1989). 'Voluntary formation of corporate audit committees among NASDAQ firms', Journal of Accounting and Public Policy, Vol. 8, pp: 239-265. 
Rabelo, F., and Vasconcelos, F. (2002). Corporate governance in Brazil.” Journal of Business Ethics. Vol. 37(3) pp. 321-335.

Raffournier, B. (1995). 'The determinants of voluntary financial disclosure by Swiss listed companies', European Accounting Review, Vol. 4, Issue 2: pp: 261-280.

Reed, D. (2002). "Corporate governance in developing countries." Journal of Business Ethics. Vol. 37(3) pp. 223-247.

Ruland, W., Tung, S., and George, N. (1990). "Factors associated with the disclosure of managers' forecasts", The Accounting Review, Vol. 65, pp: 71021.

Samaha, K. (2010) “Do Board Independence and Audit Committees Motivate Disclosure on Different Corporate Governance Information Categories in the Annual Reports in Developing Countries?" International Research Journal of Finance and Economics, No. 57, pp: 206-225.

Samaha, K. and Dahawy, K. (2010) "Factors Influencing Corporate Disclosure Transparency in the Active Share Trading Firms: An Explanatory Study", Research in Accounting in Emerging Economies, , Vol. 10, pp: 87 -118.

Samaha, K. and Dahawy, K. (2011) "An Empirical Analysis of Corporate Governance Structures and Voluntary Corporate Disclosure in Volatile Capital 
Markets: the Egyptian Experience", International Journal of Accounting, Auditing and Performance Evaluation, Vol. 7, No.s 1/2, pp: 61-93

Schadewitz, H.J., and Blevins, D.R., (1998). "Major determinants of interim disclosures in an emerging market', American Business Review, Vol. 16, No. 1, pp: 41-55.

Schipper, K. (1981). 'Discussion of voluntary corporate disclosure: The case of interim reporting', Journal of Accounting Research, Vol. 19, Issue 3, Supplement: pp: $85-88$.

Singh, H. \& Harianto, F. (1989), "Management-Board Relationships, Takeover Risk, and the Adoption of Golden Parachutes", Academy of Management Journal, March

Tengamnuay, K. and Stapleton, P. (2009) 'The role of the audit committee in Thailand: A mature monitoring mechanism or an evolving process?' Journal of Management and Governance, Vol. 13 pp131-161.

Tsamenyi, M., Enninful-Adu, E., and Onumah, J. (2007). "Disclosure and corporate governance in developing countries: Evidence from Ghana." Managerial Auditing Journal. Vol. 22(3) pp. 319-334.

UNCTAD (2007) '2007 Review of the implementation status of corporate governance disclosures: case study Egypt', Report TD/ B/COM.2 /ISAR/CRP.7 by the UNCTAD secretariat available at UNCTAD.org 
UNCTAD (2006) '2006 Review of the implementation status of corporate governance disclosures' Report TD/ B/COM.2 /ISAR/CRP.3 by the UNCTAD secretariat available at UNCTAD.org

Weir, C., and Laing, D. (2003). 'Ownership structure, board composition and the market for corporate control in the UK: An empirical analysis', Applied Economics, Vol. 35, pp: 1747-1759.

Williams, S.M. (2002). 'Board of director determinants of voluntary audit committee disclosures: Evidence from Singapore', Working paper, Singapore Management University.

Willekens, M., Bauwhede, H., V., Gaeremynck, H., V., Ann, H., V., Gucht, L., V., D. (2005). The impact of internal and external governance mechanisms on the voluntary disclosure of financial and non-financial performance. BAA Auditing Research Conference. Birmingham (UK), Aston Business School.

Xie, B., Davidson III, W.N. and DaDalt, P.J. (2001). 'Earnings management and corporate governance: The roles of the board and the audit committee', Working paper, Southern Illinois University.

Yermack, D. (1996), "Higher market valuation of companies with a small board of directors", Journal of Financial Economics, Vol. 40 pp.185-211.

Young, M., Peng, M., Ahlstrom, D., Bruton, G., and Jiang, Y. (2008) “Corporate Governance in Emerging Economies: A Review of the Principal-Principal Perspective.” Journal of Management Studies, Vol. 45(1) pp 196-220. 
World Bank (2009), "Report on the observance of standards and codes (ROSC): a corporate governance country assessment for The Arab Republic of Egypt “, Egypt, Cairo, June. 
Table 1

\section{Model Specification and Variable Measurement}

\begin{tabular}{|c|c|c|c|c|}
\hline $\begin{array}{l}\text { Abbreviated } \\
\text { variable name }\end{array}$ & Full variable name & Variable description & $\begin{array}{l}\text { Predicted } \\
\text { sign }\end{array}$ & Data source \\
\hline \multicolumn{5}{|c|}{ Dependent variables } \\
\hline EXTCGDIS & Overall CG disclosure index & Percent of overall applicable CG disclosure items supplied/satisfied & & Annual reports \\
\hline OSE & $\begin{array}{l}\text { Ownership Structure and Exercise of } \\
\text { Control Rights disclosure sub index }\end{array}$ & $\begin{array}{l}\text { Percent of applicable disclosure index items supplied/satisfied for } \\
\text { the OSE sub index }\end{array}$ & & Annual reports \\
\hline FT & $\begin{array}{l}\text { Financial Transparency and Information } \\
\text { disclosure sub index }\end{array}$ & $\begin{array}{l}\text { Percent of applicable disclosure index items supplied/satisfied for } \\
\text { the FT sub index }\end{array}$ & & Annual reports \\
\hline AUD & Auditing disclosure sub index & $\begin{array}{l}\text { Percent of applicable disclosure index items supplied/satisfied for } \\
\text { the AUD sub index }\end{array}$ & & Annual reports \\
\hline $\mathrm{CR}$ & $\begin{array}{l}\text { Corporate Responsibility and compliance } \\
\text { disclosure sub index }\end{array}$ & $\begin{array}{l}\text { Percent of applicable disclosure index items supplied/satisfied for } \\
\text { the CR sub index }\end{array}$ & & Annual reports \\
\hline $\mathrm{BM}$ & $\begin{array}{l}\text { Board and Management Structure and } \\
\text { Process disclosure sub index }\end{array}$ & $\begin{array}{l}\text { Percent of applicable disclosure index items supplied/satisfied for } \\
\text { the BM sub index }\end{array}$ & & Annual reports \\
\hline \multicolumn{5}{|c|}{ Independent Variables } \\
\hline $\mathrm{BCOM}$ & Board Composition & $\begin{array}{l}\text { Ratio of the number of non-executive directors to the total number } \\
\text { of the directors }\end{array}$ & + & $\begin{array}{l}\text { Ownership structure information } \\
\text { (EGID), Board of directors' report } \\
\text { (EGID) }\end{array}$ \\
\hline BOSIZE & Board Size & The number of board members & + & $\begin{array}{l}\text { Ownership structure information } \\
\text { (EGID), Board of directors' report } \\
\text { (EGID) }\end{array}$ \\
\hline DUALT & Duality in position & $\begin{array}{l}\text { Dummy variable; }=1 \text { when the company's CEO servers as a board } \\
\text { chairman, }=0 \text { otherwise }\end{array}$ & - & $\begin{array}{l}\text { Ownership structure information } \\
\text { (EGID), Board of directors' report } \\
\text { (EGID) }\end{array}$ \\
\hline DIR & Director ownership & $\begin{array}{l}\text { Percentage of shares owned by the CEO and executive directors to } \\
\text { the total number of shares issued. }\end{array}$ & - & $\begin{array}{l}\text { Ownership structure information } \\
\text { (EGID) }\end{array}$ \\
\hline BLK & Block-holder ownership & $\begin{array}{l}\text { Percentage of shares owned by the block-holders-shareholders } \\
\text { whose ownership equal to or exceeds } 5 \% \text { to the total number of } \\
\text { shares issued. }\end{array}$ & - & $\begin{array}{l}\text { Ownership structure information } \\
\text { (EGID) }\end{array}$ \\
\hline NS & Number of shareholders & Number of the owners holding the total number of shares issued. & + & $\begin{array}{l}\text { Ownership structure information } \\
\text { (EGID) }\end{array}$ \\
\hline
\end{tabular}




\section{Corporate Governance Disclosure And Its Determinants In Egypt}

Control Variables

LEV

LGSIZE

PRO

Leverage

Firm size

Profitability

INDT
Dummy variable $=1$ if the company has an audit committee, $=0$ otherwise

Long-term debt / total assets

Natural logarithm of total assets

Net income before tax / total stockholders 'equity.

Dummy variable; $=1$ if the company is manufacturing, $=0+$ otherwise
Board of directors' report (EGID)

Annual report: Financial statements Annual report: Financial statements Annual report: Financial statements EGX Bulletin (December 2009) 
Table 2

\section{Corporate Governance disclosure index (Egypt compared with 2 UNCTAD reports)}

CG Disclosures

\begin{tabular}{lll}
$\begin{array}{l}\text { Current Study } \\
(\text { Egypt } \% \mathrm{n}=100)\end{array}$ & $\begin{array}{l}\text { UNCTAD } \\
(\text { All } \% \mathrm{n}=105)\end{array}$ & $\begin{array}{l}\text { UNCTAD } \\
(\text { L/M Income } \mathrm{n}=63)\end{array}$ \\
\hline
\end{tabular}

\section{Panel 1: Financial Transparency [sub index FT]}

Financial and operating results *

Company objectives *

Critical accounting estimates *

Nature, type and elements of related-party transactions *

Disclosure practices on related party transactions where control exists*

Board's responsibilities regarding financial communications

The decision making process for approving transactions with related parties

Impact of alternative accounting decisions

Rules and procedure governing extraordinary transactions

$100 \quad 100 \quad 100$

$\begin{array}{lll}1000 & 92 & 90 \\ 99 & 90 & 84\end{array}$

76
94

$73 \quad 47 \quad 43$

$4 \quad 80 \quad 73$

1

0

100
84
90
3
7
54
68
57

\section{* Mandatory requirements under EAS}

Panel 2: Ownership structure and exercise of control rights [Sub index OSE]

Ownership structure

Control rights

Availability and accessibility of meeting agenda

Changes in shareholdings

Process for holding annual general meetings

Control and corresponding equity stake

Control structure

Rules and procedures governing the acquisition of corporate control in capital markets.

Anti-Takeover measures

$\begin{array}{lll}37 & 90 & 89 \\ 37 & 82 & 76 \\ 37 & 78 & 65 \\ 37 & 69 & 65 \\ 19 & 91 & 87 \\ 9 & 75 & 67 \\ 4 & 86 & 86 \\ 2 & 30 & 25 \\ 0 & 30 & 22\end{array}$




\section{Panel 3: Board and management structure and process [Sub Index BM]}

Risk management objectives, system and activities *

Composition of board of directors (executives and non-executives)

Independence of the board of directors

Number of outside board and management position directorships held by the directors

Types and duties of outside board and management positions

Existence of plan of succession

Qualifications and biographical information on board members

Determination and composition of directors' remuneration

"Checks and balances" mechanisms

Governance structures, such as committees and other mechanisms to prevent conflict of interest

Composition and function of governance committee structures

Role and functions of the board of directors

Professional development and training activities

Duration of director's contracts

Compensation policy for senior executives departing the firm as a result of a merger or acquisition

Existence of procedure(s) for addressing conflicts of interest among board members

Performance evaluation process

Material interests of members of the board and management

Availability and use of advisorship facility during reporting period

\section{* Mandatory requirements under EAS}

\section{Panel 4: Corporate responsibility and compliance [Sub Index CR]}

Policy and performance in connection with environmental and social responsibility

Impact of environmental and social responsibility policies on the firm's sustainability

Mechanisms protecting the rights of other stakeholders in business

A Code of Ethics for the Board and waivers to the ethics code

89

99

68

79

74

52

83

68

88

88

86

84

36

76

38

67

67

57

41

83

98

71

62

46

81

54

84

81

83

78

27

62

27

57

52

33 


\section{Corporate Governance Disclosure And Its Determinants In Egypt}

A Code of Ethics for all company employees

The role of employees in corporate governance

Policy on "whistle blower" protection for all employees

Panel 5: Auditing [Sub Index AUD]

Board confidence in independence and integrity of external auditors

Process for interaction with external auditors

Process for appointment of internal auditors / Scope of work and responsibilities

Internal control systems

Duration of current auditors

Rotation of audit partners

Process for interaction with internal auditors

Process for appointment of external auditors

Auditors' involvement in non-audit work and the fees paid to the auditors

1

1

0

0
17

35

41

57

76

67

17

13

60

75

41 
Table 3

Descriptive Statistics on the Independent Variables

\begin{tabular}{llllll}
\hline Variable & $\mathrm{N}$ & Minimum & Maximum & Mean & Std. Deviation \\
\hline Board Composition & 100 & .00 & .96 & .5594 & .35537 \\
Board Size & 100 & .00 & 30.00 & 10.4200 & 5.77382 \\
Duality in position & 100 & .00 & 1.00 & .6100 & .49021 \\
Director ownership & 100 & .00 & .97 & .0896 & .21860 \\
Block-holder ownership & 100 & .00 & 1.00 & .5710 & .34468 \\
Number of shareholders & 100 & 3.00 & 95.00 & 16.8400 & 14.52043 \\
Existence of Audit Committees & 100 & .00 & 1.00 & .2200 & .41633 \\
Leverage & 100 & .00 & 7.66 & .5708 & 1.26746 \\
Firm size* & 100 & 157 & 38,000 & 3700 & $6.95799 \mathrm{E} 9$ \\
Profitability & 100 & -1.34 & 1.18 & .2082 & .27757 \\
Industry type & 100 & .00 & 1.00 & .5500 & .50000 \\
\hline
\end{tabular}

Notes: * In million EGP 


\section{Table 4}

\section{Descriptive Statistics on the Dependent Variables}

\begin{tabular}{|c|c|c|c|c|c|}
\hline Variable & Range & Minimum & Maximum & Mean & Std. Dev \\
\hline \multicolumn{6}{|l|}{ Panel 1: Overall corporate governance score for EGX 100 companies } \\
\hline Overall Corporate Governance Disclosure Index & .60 & .06 & .66 & .16 & .10094 \\
\hline \multicolumn{6}{|l|}{ Panel 2: Corporate Governance disclosure sub-indices } \\
\hline Financial Transparency and Information Disclosure Sub-Index (FT) & .56 & .33 & .89 & .50 & .10567 \\
\hline $\begin{array}{l}\text { Ownership Structure and Exercise of Control Rights Sub-Index } \\
\text { (OSE) }\end{array}$ & .78 & .00 & .78 & .20 & .25831 \\
\hline Board and Management Structure and Process Sub-Index (BM) & .74 & .00 & .74 & .10 & .14106 \\
\hline Corporate Responsibility and Compliance Sub-Index (CR) & .57 & .00 & .57 & .03 & .10269 \\
\hline Auditing Sub-Index (AUD) & .33 & .00 & .33 & .01 & .04639 \\
\hline
\end{tabular}




\section{Table 5}

Pearson correlation coefficients between dependent and independent variables $(N=100)$

\begin{tabular}{|l|l|l|l|l|l|l|l|l|l|l|l|l|}
\hline & EXTCGDIS & NS & BLK & DIR & BCOM & BOSIZE & DUALT & ACO & LEV & LGSIZE & PRO & INDT \\
\hline EXTCGDIS & 1 & & & & & & & & & & \\
\hline NS & $.482^{* *}$ & 1 & & & & & & & & & \\
\hline BLK & $-.577^{* *}$ & $-.470^{* *}$ & 1 & & & & & & & & & \\
\hline DIR & .025 & -.049 & .149 & 1 & & & & & & & & \\
\hline BCOM & $.496^{* *}$ & $.214^{*}$ & $-.303^{* *}$ & -.091 & 1 & & & & & & & \\
\hline BOSIZE & -.035 & .120 & .046 & .056 & -.003 & 1 & & & & & & \\
\hline DUALT & $-.620^{* *}$ & $-.269^{* *}$ & $.569^{* *}$ & .081 & $-.422^{* *}$ & .098 & 1 & & & & & \\
\hline ACO & .185 & .053 & $-.209^{*}$ & .006 & $.295^{* *}$ & .033 & $-.219^{*}$ & 1 & & & & \\
\hline LEV & .046 & -.008 & -.069 & .069 & .048 & -.064 & -.060 & .091 & 1 & & & \\
\hline LGSIZE & $.547^{* *}$ & $.341^{* *}$ & $-.280^{* *}$ & -.059 & $.253^{*}$ & .066 & $-.214^{*}$ & .071 & .132 & 1 & & \\
\hline PRO & .140 & .079 & -.016 & -.038 & .022 & .039 & .038 & .021 & $-.267^{* *}$ & .080 & 1 \\
\hline INDT & -.100 & -.049 & .001 & .071 & -.102 & .063 & .060 & -.102 & -.107 & $-.289^{* *}$ & .031 & 1 \\
\hline
\end{tabular}

$*$ Correlation is significant at the 0.05 level (2-tailed). $\quad * *$ Correlation is significant at the 0.01 level (2-tailed). 
Table 6

Ordinary Least Squares (OLS) Regression Results of the Corporate Governance Disclosure Scores on Test and Control Variables $(\mathrm{N}=100)$

\begin{tabular}{|c|c|c|c|c|c|c|c|c|c|c|c|c|}
\hline \multirow{2}{*}{$\begin{array}{l}\text { Dependent variable } \\
\text { Adjusted R-square }\end{array}$} & \multirow{2}{*}{$\begin{array}{l}\text { Overall } \\
\text { disclosure } \\
61.8 \%\end{array}$} & $\begin{array}{l}\text { Corporate } \\
\text { index }\end{array}$ & \multirow[t]{2}{*}{ governance } & \multicolumn{3}{|c|}{$\begin{array}{l}\text { Ownership structure and exercise of } \\
\text { control rights [Sub index OSE] }\end{array}$} & \multicolumn{3}{|c|}{$\begin{array}{l}\text { Financial Transparency [sub index } \\
\text { FT] }\end{array}$} & \multicolumn{3}{|c|}{$\begin{array}{l}\text { Board and management structure } \\
\text { and process [Sub Index BM] }\end{array}$} \\
\hline & & & & $51.6 \%$ & & & $15.4 \%$ & & & $45.6 \%$ & & \\
\hline F-value & 15.56 & & & 10.59 & & & 2.64 & & & 8.56 & & \\
\hline P-value & $.000^{* * *}$ & & & $.000^{* * *}$ & & & $.006^{* * *}$ & & & $.000^{* * *}$ & & \\
\hline Durbin Watson Test & 1.756 & & & 1.873 & & & 1.766 & & & 1.876 & & \\
\hline Parameter & $\begin{array}{l}\text { Coeff. } \\
\text { Est. }\end{array}$ & $\begin{array}{l}\text { T- } \\
\text { statistic }\end{array}$ & P-value & Coeff. Est. & T-statistic & $\mathrm{P}$-value & $\begin{array}{l}\text { Coeff. } \\
\text { Est. }\end{array}$ & $\begin{array}{l}\mathrm{T}- \\
\text { statistic }\end{array}$ & $\mathrm{P}$-value & Coeff. Est. & $\begin{array}{l}\text { T- } \\
\text { statistic }\end{array}$ & P-value \\
\hline Intercept & Included & & & Included & & & Includec & & & Included & & \\
\hline H1 - BCOM & .228 & 3.065 & $.003^{\star * *}$ & .186 & 2.217 & $.029^{\star *}$ & .261 & 2.359 & $.021^{* *}$ & .140 & 1.577 & .118 \\
\hline H2 - BOSIZE & -.031 & -.479 & .633 & -.049 & -.684 & .496 & .024 & .252 & .801 & -.022 & -.284 & .777 \\
\hline H3 - DUALT & -.341 & -4.430 & $.000^{* * *}$ & -.495 & -5.709 & $.000^{\star \star *}$ & -.092 & -.801 & .425 & -.177 & -1.932 & $.057^{*}$ \\
\hline H4 - DIR & .024 & .370 & .712 & -.013 & -.178 & .859 & .128 & 1.320 & .190 & -.003 & -.034 & .973 \\
\hline H5- BLK & -.230 & -2.686 & $.009^{\star \star \star}$ & -.202 & -2.095 & $.039^{\star *}$ & -.003 & -.024 & .981 & -.205 & -2.003 & $.048^{\star *}$ \\
\hline H6 - NS & .010 & .122 & .903 & -.065 & -.723 & .472 & .001 & .007 & .995 & .053 & .551 & .583 \\
\hline $\mathrm{H} 7$ - ACO & -.025 & -.370 & .712 & .079 & 1.042 & .300 & -.132 & -1.325 & .189 & -.112 & -1.397 & .166 \\
\hline LEV - Control & .034 & .502 & .617 & -.028 & -.372 & .711 & .077 & .764 & .447 & .011 & .139 & .890 \\
\hline LGSIZE- Control & .347 & 4.787 & $.000^{\star \star \star}$ & .113 & 1.391 & .168 & .288 & 2.673 & $.009^{\star \star \star}$ & .419 & 4.847 & $.000^{\star * *}$ \\
\hline PRO-Control & .050 & .782 & .436 & -.013 & -.181 & .857 & -.151 & -1.569 & .120 & .075 & .973 & .333 \\
\hline INDT- Control & .047 & .698 & .487 & .090 & 1.203 & .232 & .129 & 1.293 & .199 & -.080 & -1.002 & .319 \\
\hline
\end{tabular}


*significant at the $10 \%$ level $* *$ significant at the $5 \%$ level $\quad * * *$ significant at the $1 \%$

\section{Table 7}

Binary Logistic Regression Results of the Corporate Governance Disclosure Scores on Test and Control Variables ( $\mathrm{N}=100)$

\begin{tabular}{llll}
\hline & Corporate responsibility and compliance [Sub Index CR] \\
\hline Pseudo R-square & $63 \%$ & & \\
Model Chi-square & 35.80 & & \\
Significance (P-Value) & $.000^{* * *}$ & & \\
Percentage correctly classified & 96 & & Sig. (P- value) \\
\hline Parameter & Estimate & & \\
\hline Intercept & Included test value & .361 \\
H1 - BCOM & 3.622 & .835 & .999 \\
H2 - BOSIZE & .000 & .000 & .916 \\
H3 - DUALT & -.182 & .011 & .352 \\
H4 - DIR & -4.061 & .868 & $.098^{*}$ \\
H5 - BLK & -4.910 & 2.615 & .450 \\
H6 - NS & .023 & .571 & $.065^{*}$ \\
H7 - ACO & 2.133 & 3.410 & .815 \\
LEV- Control & -.113 & .055 & .408 \\
LGSIZE- Control & .000 & .684 &
\end{tabular}


Corporate Governance Disclosure And Its Determinants In Egypt

PRO- Control

3.666

3.034

.082

INDT-Control

2.617

3.197

$.074^{*}$

*significant at the $10 \%$ level $* *$ significant at the $5 \%$ level 